\title{
UDZIAŁ POLSKICH PUBLIKACJI BIBLIO- I INFORMATOLOGICZNYCH W OTWARTYCH ZASOBACH WIEDZY: PRZYKŁAD E-LIS
}

\author{
Małgorzata Kowalska \\ Instytut Informacji Naukowej \\ i Bibliologii \\ Uniwersytet M. Kopernika w Toruniu
}

Bibliotekoznawstwo, Eprints for Library and Information Science (E-LIS), nauka o informacji, Open Access, otwarte zasoby wiedzy, repozytoria cyfrowe

Powszechna dostępność infrastruktury sieciowej sprawia, że dorobek naukowy może być dziś rozpowszechniany bardzo szeroko i na wielu poziomach. Możliwości takie stwarza ruch Open Access, który powstał jako reakcja na rosnące ceny prenumeraty czasopism, monopolistyczne praktyki wydawców i dostawców informacji oraz mankamenty wynikające z samego procesu publikowania (ograniczone limity przyjmowania prac, opóźnienia procesu wydawniczego). Głównym założeniem tej, sięgającej tradycjami jeszcze lat 90. XX wieku (uruchamianych wówczas w Stanach Zjednoczonych pierwszych otwartych archiwów dokumentów elektronicznych) inicjatywy jest zapewnienie nieograniczonego, powszechnego, trwałego i globalnego dostępu do elektronicznych zasobów wiedzy wszystkim użytkownikom Internetu oraz lobbowanie na rzecz zmiany sposobu myślenia o udostępnianiu i finansowaniu publikacji'.

Jednym z modeli realizacji idei Open Access w praktyce sa - obok czasopism naukowych udostępnianych online - repozytoria ${ }^{2}$. Ich głównym zadaniem jest gromadzenie i zachowywanie efektów twórczości intelektualnej specjalistów z danej dziedziny bądź pracowników określonej instytucji. Do repozytoriów trafiają tzw. eprinty (ang. eprints lub e-prints), a więc dokumenty udostępniane przed opublikowaniem w publikacjach tradycyjnych (ang. preprints) oraz wersje artykułów opublikowane w czasopismach zazwyczaj po przejściu procesu recenzji (ang. postprints) ${ }^{3}$. Przyrost zasobów repozytoriów następuje poprzez autoarchiwizację (ang. self-archiving), która polega na deponowaniu dokumentu przez samego autora lub redaktora współpracującego z zasobem. Decydując

1 J. Hofmokl [et al.]: Przewodnik po otwartej nauce. Warszawa: Interdyscyplinarne Centrum Modelowania Matematycznego i Komputerowego Uniwersytetu Warszawskiego. 2009, 94 s. [online].[dostęp: 27.08. 2012]. Dostępny w World Wide Web: <http://otwartanauka.pl/wp-content/uploads/2010/01/przewodnik-po-otwartej-nauce.pdf>.

2 Terminy repozytorium, archiwum i zasób są w niniejszym opracowaniu używane synonimicznie.

${ }^{3}$ M. Nahotko: Komunikacja naukowa w środowisku cyfrowym: Globalna biblioteka cyfrowa w informatycznej infrastrukturze nauki. Warszawa 2010, s. 93. 
się na umieszczenie publikacji w archiwum cyfrowym, twórca poświadcza jej oryginalność oraz udziela jego organizatorom praw niewyłącznych na udostępnianie dzieła. Jeśli włączanie pracy do zasobu przebiega za pośrednictwem redaktora, wówczas autor powiadamia go o autentyczności i wiarygodności pracy oraz wyraża zgodę na archiwizację i udostępnianie, a redaktor nadaje metadane i odpowiedni format dokumentu (ang. mediated deposit).

Przykładem repozytorium, którego zasób zasilany jest z kilku źródeł (autorzy publikacji, edytorzy krajowi, organizatorzy konferencji, inni zarejestrowani użytkownicy), jest Eprints for Library and Information Science (dalej: E-LIS). To pierwsze, otwarte, elektroniczne archiwum rejestrujące materiały z zakresu bibliotekoznawstwa i informacji naukowej oraz nauk pokrewnych rozwija się nieprzerwanie od 2003 r. i jest miejscem, w którym teoretycy i praktycy obu dyscyplin moga popularyzować swój dorobek publikacyjny, a jednocześnie w sposób nieograniczony korzystać z wyników prac innych badaczy. Od 2005 r. udział w nim mają także publikacje polskie. Niniejszy artykuł dotyczy właśnie tej części E-LIS. Dokonano w nim analizy publikacji polskich pod względem częstotliwości ich zamieszczania, dat wydania, rodzaju deponowanych dokumentów oraz zagadnień najczęściej obecnych na ich łamach.

\section{Repozytorium E-LIS - informacje podstawowe}

E-LIS stanowi część rozwijanego od 1999 r. projektu Research in Computing, Library and Information Science, mającego na celu budowę międzynarodowej bazy danych o bieżących i archiwalnych badaniach prowadzonych w takich dziedzinach jak informatyka, bibliotekoznawstwo i informacja naukowa ${ }^{4}$. Jako przedsięwzięcie non profit, E-LIS zarządzane i utrzymywane jest przez zespół bibliotekarzy-wolontariuszy z całego świata 5 .

Publikacje przekazywane do E-LIS traktowane sa jako depozyt, co oznacza, że autorzy w każdej chwili mogą wycofać zgodę na ich udostępnianie. Jednocześnie, przekazując teksty do elektronicznej archiwizacji, twórcy deklarują, że sa one ich własnością intelektualna, a prawa do nich, zwłaszcza do wykorzystywania na elektronicznym polu eksploatacji, nie zostały przekazane innemu podmiotowi (np. wydawcy ${ }^{6}$ ). Warunkiem decydującym o przyjęciu publikacji do archiwum jest jego wartość naukowa oraz zgodność z profilem tematycznym zasobu. Każdy dokument, opublikowany bądź dopiero przeznaczony do druku,

${ }^{4}$ About rclis Research in computing, library and information science. [online]. [dostęp: 27.08.2012]. Dostępny w World Wide Web: <http://rclis.org/about.html>.

${ }^{5}$ A. De Robbio, P. Sequeiros: Open archives for Library and Information Science: an international experience (Ogólnodostępne archiwa a informacja naukowa i biblioteczna - doświadczenia globalne). Tł. J. Grześkowiak. W: IV Ogólnopolska Konferencja EBIB: Internet w bibliotekach. Open Access, Toruń (Poland), 7-8 December 2007 Warszawa: SBP, Komisja Wydawnictw Elektronicznych, 2007 (Materiały konferencyjne EBIB, nr 18). [online]. [dostęp: 27.08.2012]. Dostępny w World Wide Web: <http://www.ebib.info/publikacje/matkonf/mat18/de_robbio.php>.

${ }^{6}$ Informacji na temat polityki poszczególnych wydawców w zakresie praw autorskich i kwestii autoarchiwizacji dostarcza serwis SHERPA/RoMEO. Zob. SHERPA/RoMEO [on line]. [dostęp: 27.08.2012]. Dostępny w World Wide Web: <http://www.sherpa.ac.uk/romeo/>. 
w dowolnym języku i formacie może stać się częścią tego repozytorium i zostać udostępniony w pełnotekstowej wersji szerokiej publiczności na całym świecie. W repozytorium gromadzone są 23 typy dokumentów, od książek i ich fragmentów, przez artykuły z gazet i czasopism, po prezentacje multimedialne, plakaty, raporty i prace dyplomowe. Dla każdego typu dokumentu opracowano specjalny schemat metadanych (w standardzie Dublin Core). Po przygotowaniu opisu bibliograficznego publikacji przez autora bądź edytora podlega on jeszcze weryfikacji komitetu redakcyjnego ${ }^{7}$.

Zawartość E-LIS została zorganizowana według dwóch struktur: słów kluczowych oraz schematu anglojęzycznej klasyfikacji JITA z zakresu bibliotekoznawstwa i informacji naukowej, opracowanej przez Jose Manuela Barrueco Cruz, Immę Subirats Coll, Thomasa Krichel i Antonellę De Robbio (akronim od imion twórców) oraz porządku geograficznego (kontynent i kraj). Zaletą tej klasyfikacji jest to, iż została przygotowana specjalnie dla potrzeb klasyfikacji piśmiennictwa z zakresu bibliotekoznawstwa i nauki o informacji, a w 2011 r. przetłumaczona na kilka języków, w tym na język polski ${ }^{8}$.

Dostęp do zasobów umożliwiają opcje przeglądania (według 8 indeksów) oraz wyszukiwania (prostego i zaawansowanego). Użytkownik może także wygenerować statystyki wykorzystywania danej publikacji, wyświetlić pozycje ostatnio dodane oraz polecić repozytorium w serwisach społecznościowych.

Pod koniec 2010 r. E-LIS został przeniesiony z platformy GNU Eprints na DSpace $^{9}$, co ma zapewniać właściwy poziom zabezpieczeń danych oraz współpracę z innymi systemami (np. indeksowanie przez wyszukiwarki Open Archive Initiatives $)^{10}$. Do końca lipca 2012 r. w repozytorium zdeponowanych zostało 13537 publikacji.

\section{Polska część E-LIS - zarys statystyczny}

Polska dość szybko, bo już 2 lata po uruchomieniu repozytorium zaangażowała się w jego budowę. Przygotowanie polskiej części odbywa się na analogicznych zasadach jak reszta zasobu. Zanim tekst zostanie umieszczony w bazie, muszą zostać spełnione określone kryteria formalne: autor deponujący publikację musi bezpłatnie zarejestrować się w serwisie, za pomocą przesłanego e-mailem odnośnika potwierdzić aktywację konta i wprowadzić dane osobowe. Aby zdeponować publikację, należy zalogować się do repozytorium i wypełnić

${ }^{7}$ A. De Robbio, P. Sequeiros: Open archives..., op. cit.

${ }^{8}$ L. Derfert-Wolf: Międzynarodowe repozytorium z zakresu bibliotekoznawstwa i informacji naukowej E-LIS. W: Otwarte zasoby wiedzy: nowe zadania uczelni i bibliotek w rozwoju komunikacji naukowej. Materiały konferencyjne, Kraków-Zakopane, 15-17 czerwca 2011. Praca zbiorowa pod red. M. Górskiego i M. Marcinek. Kraków 2011, s. 214.

${ }^{9}$ Według danych pochodzących z autorytatywnego katalogu repozytoriów akademickich OpenDoar DSpace jest oprogramowaniem najczęściej wdrażanym do budowy i obsługi zasobów cyfrowych. Por. OpenDOAR Charts - Worldwide. The Directory of Open Access Repositories - OpenDOAR [online]. [dostęp: 27.08.2012]. Dostępny w World Wide Web: <http://www.opendoar.org/find.php?format=charts>.

${ }^{10}$ About E-LIS. E-LIS. E-prints in Library and Information Science. [online]. [dostęp: 27.08.2012]. Dostępny w World Wide Web: <http://eprints.rclis.org/cms/about>. 
formularz zawierający poszczególne elementy opisu bibliograficznego wprowadzanej do zasobu pozycji (autor, tytuł, abstrakt, słowa kluczowe, źródło publikacji, rok, nr, część, strony, instytucja, wydawca, bibliografia, status publikacji, język, kraj, streszczenie, itp.). Publikacja powinna zostać także opisana według klasyfikacji JITA. Podczas redagowania opisu rzeczowego należy sugerować się hasłami i słowami kluczowymi istniejącymi już w bazie i w ten sposób starać się zachowywać jednolitość metadanych. W przypadkach wątpliwych można zwrócić się o pomoc do polskich redaktorek, tj. Bożeny Bednarek-Michalskiej (Biblioteka Uniwersytecka w Toruniu) i Lidii Derfert-Wolf (Biblioteka Główna Uniwersytetu Technologiczno-Przyrodniczego w Bydgoszczy). Po zakończeniu procesu tworzenia metadanych należy przesłać publikację ${ }^{11}$.

Na dzień 31 lipca 2012 r. w repozytorium znajdowało się 320 prac autorów, którzy jako kraj pochodzenia wskazali Polskę. Mimo że stanowi to zaledwie $2,4 \%$ całego zasobu E-LIS, to dane $z$ analogicznego okresu roku poprzedniego, kiedy w repozytorium zarejestrowanych było 219 polskich publikacji, pozwalaja wnioskować o przyroście rodzimego zasobu o około $46 \%$ (całego E-LIS zaledwie o $11 \%)^{12}$.

Do polskich autorów i/lub redaktorów, których prac w E-LIS odnotowano najwięcej, należa: Marek Władysław Kolasa (62), Lidia Derfert-Wolf (49), Barbara Szczepańska (34) oraz Maria Kocójowa (31). Warto w tym miejscu zauważyć, że przy przeglądaniu zasobu według haseł autorskich (opcja „Browse”) jako rezultat wyszukiwania wyświetlają się wszystkie dokumenty, w metadanych których występuje podane przez użytkownika nazwisko. Nie są to zatem wyłącznie publikacje autorskie, lecz także dokumenty wprowadzone do zasobu przez daną osobę, wskazujące na nią jako redaktora materiałów pokonferencyjnych czy autora pozycji występującej w literaturze przedmiotu.

Mimo możliwości przesyłania aż 23 typów dokumentów na „zbiór polski” złożyły się przede wszystkim artykuły stanowiące pokłosie wystapień konferencyjnych (120 pozycji), fragmenty prac zbiorowych (51) oraz artykuły pochodzace z czasopism drukowanych (46) i elektronicznych (35). Stosunkowo licznie reprezentowane były także preprinty (26) i prezentacje multimedialne (23). Z kolei udział książek, recenzji, prac dyplomowych i projektów ocenić należy jako niewielki (od 1 do 2 pozycji) (zob. wykres 1). Całkowicie nieobecne sa wydawnictwa pokonferencyjne (w całości), zbiory danych, przewodniki i artykuły z gazet.

11 Więcej nt. historii, struktury zarządzania i procedur deponowania publikacji w E-LIS zob.: L. Derfert-Wolf: E-LIS - archiwum publikacji z zakresu bibliotekoznawstwa i informacji naukowej. W: II Konferencja Biblioteki Politechniki Łódzkiej: Biblioteki XXI wieku: Czy przetrwamy EBIB?, Łódź,19-21 czerwca 2006 r. Warszawa: SBP, Komisja Wydawnictw Elektronicznych, Politechnika Łódzka, 2006 (materiały konferencyjne EBIB, nr 16). [online]. [dostęp: 27.08.2012]. Dostępny w World Wide Web: <http://www.ebib.info/publikacje/matkonf/biblio21/poster_ref02.pdf>; B. Bednarek-Michalska, L. Derfert-Wolf: E-LIS - archiwum publikacji z zakresu bibliotekoznawstwa i informacji naukowej. Uwagi praktyczne dla polskich autorów. EBIB Elektroniczny Biuletyn Informacyjny Bibliotekarzy 2006, nr 3 (73). [online]. [dostęp: 27.08.2012]. Dostępny w World Wide Web: <http://ebib.info/2006/73/michalska_wolf.php>.

${ }^{12}$ L. Derfert-Wolf: Międzynarodowe repozytorium..., op. cit. 


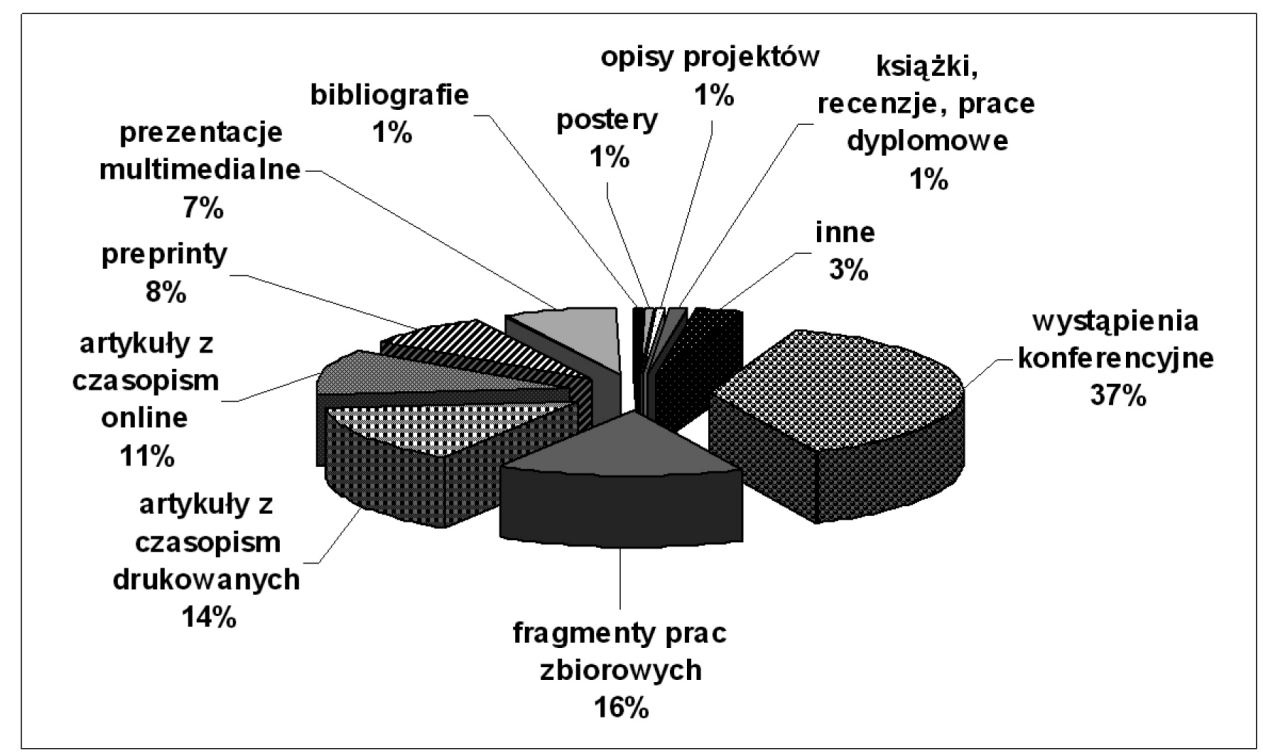

Wykres 1. Polskie publikacje w E-LIS według typów dokumentów

Źródło: Opracowanie własne na podstawie Search Results for „Poland” E-LIS. E-prints in Library and Information Science. [online]. [dostęp: 27.08. 2012]. Dostępny w World Wide Web: <http://eprints.rclis. org/handle/ 10760/ 2571/simple-search?query=>.

Aż 303 publikacje z całego „polskiego zbioru” powstały w języku polskim, dla pozostałych językiem wiodącym był: język angielski - 14, hiszpański - 2 i ukraiński - 1. Ponad połowę dokumentów (161 z całości) stanowiły publikacje recenzowane. Najczęściej do archiwizacji dokumentów wybierano format pdf (316 publikacji). Śladowa popularnościa cieszyły się formaty doc i jpeg, w których zapisano po 1 dokumencie ${ }^{13}$. Dominacja formatu pdf jest wynikiem prowadzenia świadomej polityki polskich redaktorów E-LIS, którzy zalecaja konwertowanie publikacji do tego formatu, by zapewnić polskim zbiorom jak największa widoczność w wyszukiwarkach ${ }^{14}$.

Największą liczbę polskich prac do E-LIS włączono w roku 2009 (71 publikacji), (zob. wykres 2). Zwiększoną częstotliwość wpływu odnotowano również w 2012 r. (64) oraz 2007 r. (51). Nieco mniej publikacji zasiliło repozytorium w pozostałych latach: 2006 (27), 2008 (27), 2010 (28), 2011 (42). Zdecydowanie najmniej materiałów zdeponowano w 2005 r. (zaledwie 10 pozycji), a więc w okresie uruchamiania projektu.

Jeśli chodzi o datę wydania lub przygotowania publikacji, do E-LIS najczęściej trafiały dokumenty z roku 2008 (62 pozycje). Nieco mniej datowanych było na rok 2006 (59) i rok 2009 (47). Znacząco repozytorium zasiliły także pozycje z lat 2007 (33) i 2011 (35). Mniej niż 20 archiwizacji miało miejsce w latach: 2005 i 2004. Dla pozostałych roczników $(1998,1999,2000-2003,2010,2012)$ liczba

13 Search Results for „Poland”. E-LIS. E-prints in Library and Information Science. [online]. [dostęp: 27.08.2012]. Dostępny w World Wide Web: <http://eprints.rclis.org/handle/10760/2571/simple-search?query=>.

14 L. Derfert-Wolf: Re: E-LIS. Do: M. Kowalska. 28.07.2012, 11:33 [online]. [dostęp: 27.08.2012]. Korespondencja osobista. 


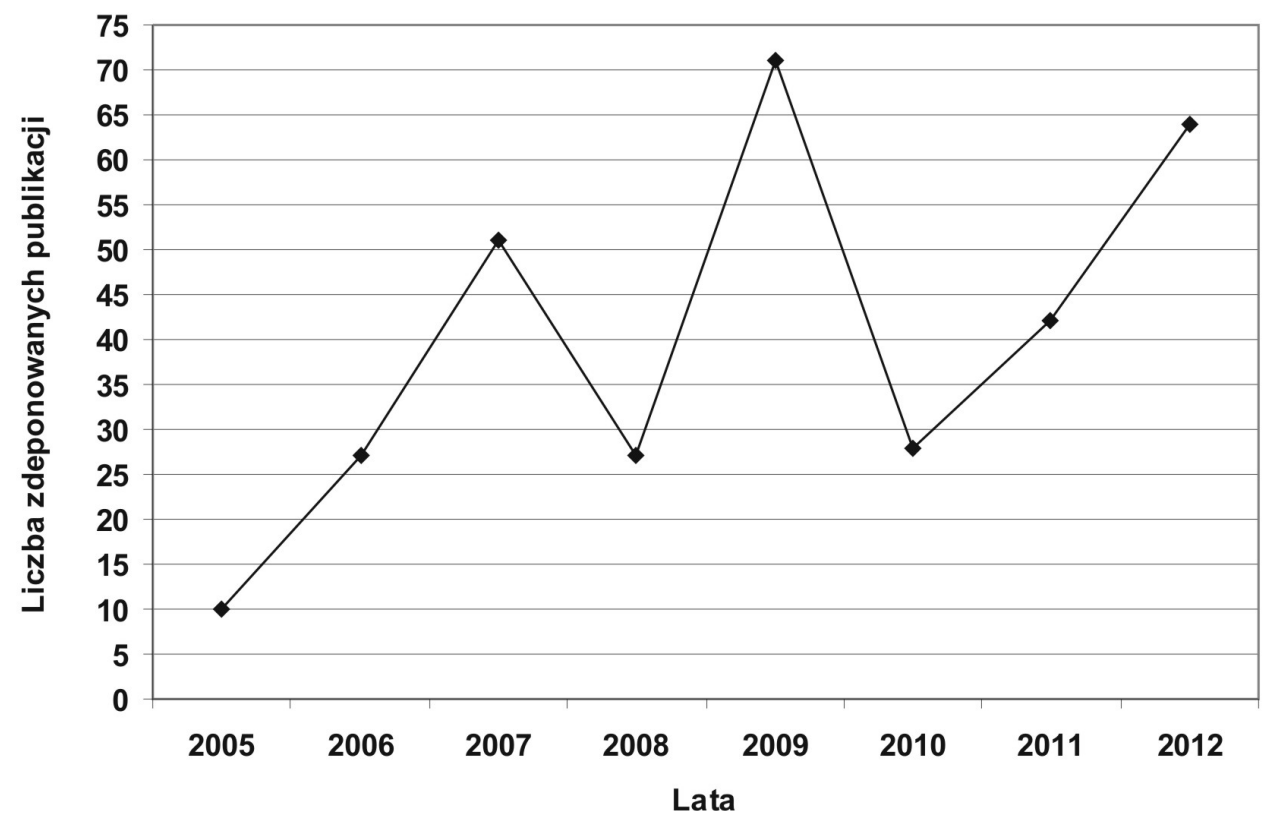

Wykres 2. Przyrost zasobów polskiej części E-LIS według dat deponowania publikacji Źródło: Opracowanie własne na podstawie: Browsing „Poland” by Submit Date. E-LIS. E-prints in Library and Information Science. [online]. [dostęp: 27.08. 2012]. Dostępny w World Wide Web: <http:// eprints.rclis.org/handle/ 10760/2571/browse?type=dateaccessioned \&submit_browse=Submit+Date>.

ta wyniosła poniżej 11 pozycji. Najstarszą zdeponowana publikacją w polskim zbiorze był referat Mirosława Górnego z roku 1988 (A Model of Library Networks Evolution), a jedną z najnowszych - preprint Zbigniewa Osińskiego z kwietnia 2012 r. (Architektura informacji polskich internetowych serwisów edukacyjnych). Różnice między datą ukazania się/powstania tekstu a umieszczeniem go w repozytorium sięgały nawet kilkunastu lat, na przykład wspomniana publikacja z 1988 r. została poddana archiwizacji dopiero w roku 2010. Z drugiej strony, do repozytorium E-LIS trafiały także takie publikacje, które zdeponowane zostały tuż po ukończeniu pracy nad nimi (jak choćby preprinty wspomnianego już Zbigniewa Osińskiego) bądź po upływie 2-4 dni od momentu ich ukazania się (drukiem lub online, np. Elżbieta Skubała, Małgorzata Rożniakowska-Kłosińska, CYRENA, czyli Cyfrowe Repozytorium Nauki Politechniki Łódzkiej) ${ }^{15}$.

\section{Polska część E-LIS - zakres tematyczny}

Jak już wspomniano, zawartość każdego dokumentu trafiającego do repozytorium E-LIS opisywana jest według haseł przedmiotowych klasyfikacji JITA oraz słów kluczowych. Deponując dokument należy z rozwijanej listy wybrać przynajmniej jedno hasło główne, ale nie więcej niż dwa, oraz dowolną liczbę

${ }^{15}$ Browsing „Poland” by Issue Year. E-LIS. E-prints in Library and Information Science. [online]. [dostęp: 27.08.2012]. Dostępny w World Wide Web: <http://eprints.rclis.org/handle/10760/2571/browse?type= issued\&submit_browse=Years $>$. 
haseł podrzędnych. Ponadto do dokumentu należy dołączyć słowa kluczowe, które powinny szczegółowiej charakteryzować treść dokumentu.

Chcąc określić zakres tematyczny polskich dokumentów w zbiorze, należy posłużyć się klasyfikacją JITA. W tym celu należy skorzystać z opcji wyszukiwania zaawansowanego bądź wyświetlić wszystkie dokumenty według kraju przy pomocy opcji „Browse”, a następnie rezultaty wyszukiwania zawęzić do określonych haseł. Ponieważ każdy dokument może zostać przypisany do przynajmniej dwóch głównych haseł przedmiotowych, liczba publikacji wyszukanych za pomocą haseł przedmiotowych i liczba publikacji wyświetlonych dla kraju nie są tożsame (w przypadku Polski nie sumują się więc do wspomnianych 320 pozycji). Sumaryczną liczbę dokumentów polskich przypisanych do poszczególnych haseł głównych prezentuje tabela1.

Tabela 1

Publikacje polskie według klasyfikacji JITA

\begin{tabular}{|r|l|c|}
\hline Lp. & \multicolumn{1}{|c|}{ Działy klasyfikacji JITA } & Liczba dokumentów \\
\hline 1. & A. Ogólne i teoretyczne aspekty bibliotek i informacji & 23 \\
\hline 2. & B. Wykorzystanie informacji i aspekty socjologiczne & 73 \\
\hline 3. & C. Użytkownicy, umiejętności informacyjne i czytelnictwo & 43 \\
\hline 4. & D. Biblioteki jako kolekcje zbiorów & 86 \\
\hline 5. & E. Publikowanie i problemy prawne & 52 \\
\hline 6. & F. Zarządzanie & 27 \\
\hline 7. & G. Przemysł informacyjny, zawód i szkolenia zawodowe & 35 \\
\hline 8. & H. Źródła i kanały informacji & 140 \\
\hline 9. & I. Usługi informacyjne i przetwarzanie informacji & 35 \\
\hline 10. & J. Obsługa techniczna w bibliotekach, archiwach i muzeach & 24 \\
\hline 11. & K. Technologie lokalne & 5 \\
\hline 12. & L. Technologie informacyjne i biblioteczne & 48 \\
\hline
\end{tabular}

Źródło: Opracowanie własne.

Dane z tabeli dowodzą, że najwięcej dokumentów sklasyfikowanych zostało za pomocą hasła „Źródła i kanały informacji”. W jego zakres weszły zarówno zagadnienia dotyczące tradycyjnych źródeł informacji (m.in. czasopism, gazet, starych druków, szarej literatury), jak i mediów elektronicznych (e-czasopism, e-booków, katalogów online, repozytoriów cyfrowych, stron internetowych). Najmniej publikacji znalazło się w dziale „Technologie lokalne”, gdzie włączono problemy budownictwa bibliotecznego, wyposażenia bibliotek, ich architektury, bezpieczeństwa i zapobiegania skutkom katastrof.

Ponieważ E-LIS nie umożliwia wyszukiwania według haseł podrzędnych, dość żmudnym procesem jest określenie, ile publikacji dotyczyło poszczególnych zakresów tematycznych wchodzących w skład haseł zasadniczych. Wnikliwą analizę utrudnia fakt, że podczas gdy niektórzy autorzy ograniczyli się wyłącznie do wskazania hasła głównego, inni charakteryzowali swoje publikacje za pomoca kilku haseł podrzędnych. Dokonując analiz, podobnie jak w przypadku liczby dokumentów wyświetlanych dla danego hasła nadrzędne- 
go, trzeba mieć więc na uwadze to, że sumaryczna liczba dokumentów wyświetlanych dla wszystkich haseł uzupełniających dane hasło główne nie jest równa liczbie dokumentów wyświetlanych dla hasła zasadniczego, ten sam dokument bowiem może zostać wyświetlony wielokrotnie, w zależności od liczby haseł podrzędnych. Przykładowo, pod hasłem ogólnym „Technologie lokalne” sklasyfikowanych zostało 5 dokumentów. Do 4 z nich dołączono tylko jedno hasło uzupełniające „Architektura”, zaś do jednego dwa hasła: „Architektura” i „Budynki bibliotek, archiwów, muzeów”. Wyszukiwanie według poszczególnych haseł uzupełniajacych i zsumowanie liczby wyświetlonych dla nich dokumentów daje więc 6 rezultatów wyszukiwania i stwarza mylne wrażenie, że do działu ogólnego (hasła nadrzędnego) należy 6 dokumentów, co nie jest prawdą. Suma dokumentów wyświetlonych dla haseł uzupełniających nie daje więc liczby dokumentów wyszukanych dla hasła głównego. Tendencję tę wyraźnie obrazuje tabela 2. Zaprezentowano w niej liczbę dokumentów polskich wyświetlona dla każdego $z$ haseł uzupełniających odrębnie. W każdym obszarze, pismem pogrubionym, wyróżniono hasło wiodące.

Tabela 2

Tematyka dokumentów polskich zarejestrowanych w E-LIS według haseł podrzędnych

\begin{tabular}{|c|c|c|}
\hline Hasła główne & Hasła uzupełniające & $\begin{array}{l}\text { Liczba } \\
\text { dokumentów }\end{array}$ \\
\hline \multirow{4}{*}{$\begin{array}{l}\text { A. Ogólne i teore- } \\
\text { tyczne aspekty } \\
\text { bibliotek i infor- } \\
\text { macji }\end{array}$} & AA. Bibliotekoznawstwo i nauka o informacji jako dyscyplina & 8 \\
\hline & AB. Teoria informacji i teoria bibliotekoznawstwa & 3 \\
\hline & $\begin{array}{l}\text { AC. Zwiazki bibliotekoznawstwa i nauki o informacji z innymi dys- } \\
\text { cyplinami }\end{array}$ & 4 \\
\hline & AZ. Inne & 4 \\
\hline \multirow{10}{*}{$\begin{array}{l}\text { B. Wykorzystanie } \\
\text { informacji i aspekty } \\
\text { socjologiczne }\end{array}$} & BA. Wykorzystanie i oddziaływanie formacji & 6 \\
\hline & BB. Metody bibliometryczne & 18 \\
\hline & BC. Informacja w społeczeństwie & 21 \\
\hline & BD. Społeczeństwo informacyjne & 7 \\
\hline & BE. Ekonomia informacji & 2 \\
\hline & BF. Polityka informacyjna & 1 \\
\hline & BG. Rozpowszechnianie i przepływ informacji & 5 \\
\hline & BH. Analiza potrzeb i oczekiwań informacyjnych & 4 \\
\hline & BI. Interfejsy użytkownika, użyteczność & 1 \\
\hline & BZ. Inne z tej kategorii & 2 \\
\hline \multirow{7}{*}{$\begin{array}{l}\text { C. Użytkownicy, } \\
\text { umiejętności } \\
\text { informacyjne i czy- } \\
\text { telnictwo }\end{array}$} & CA. Badania wykorzystania & 4 \\
\hline & CB. Badania użytkowników & 7 \\
\hline & CC. Kategorie użytkowników: dzieci, młodzież, grupy społeczne & 0 \\
\hline & $\begin{array}{l}\text { CD. Szkolenie, promocja, edukacja i działalność użytkowni- } \\
\text { ków }\end{array}$ & 12 \\
\hline & CE. Umiejętności & 1 \\
\hline & CF. Czytelnictwo i przekaz ustny & 0 \\
\hline & CZ. Inne z tej kategorii & 6 \\
\hline
\end{tabular}




\begin{tabular}{|c|c|c|}
\hline \multirow{14}{*}{$\begin{array}{l}\text { D. Biblioteki jako } \\
\text { kolekcje zbiorów }\end{array}$} & DA. Biblioteki światowe & 1 \\
\hline & DB. Biblioteki narodowe & 4 \\
\hline & DC. Biblioteki publiczne & 5 \\
\hline & DD. Biblioteki akademickie & 62 \\
\hline & DE. Biblioteki szkolne & 1 \\
\hline & DF. Biblioteki rządowe & 0 \\
\hline & DG. Biblioteki prywatne & 0 \\
\hline & DH. Biblioteki specjalne & 4 \\
\hline & DI. Biblioteki naukowe & 3 \\
\hline & DJ. Biblioteki techniczne & 1 \\
\hline & DK. Biblioteki ochrony zdrowia i medyczne & 5 \\
\hline & DL. Archiwa & 0 \\
\hline & DM. Muzea & 0 \\
\hline & DZ. Inne z tej kategorii & 1 \\
\hline \multirow{7}{*}{$\begin{array}{l}\text { E. Publikowanie i pro- } \\
\text { blemy prawne }\end{array}$} & EA. Środki masowego przekazu & 37 \\
\hline & $\begin{array}{l}\text { EB. Poligrafia, wydawnictwa elektroniczne, transmisje audiowi- } \\
\text { zualne }\end{array}$ & 5 \\
\hline & EC. Rynek księgarski & 0 \\
\hline & $\begin{array}{l}\text { ED. Własność intelektualna, prawo autorskie, prawo własności, } \\
\text { copyright i copyleft }\end{array}$ & 4 \\
\hline & EE. Wolność intelektualna & 0 \\
\hline & EF. Cenzura & 0 \\
\hline & EZ. Inne $z$ tej kategorii & 0 \\
\hline \multirow[t]{10}{*}{ F. Zarządzanie } & FA. Współpraca & 2 \\
\hline & FB. Marketing & 1 \\
\hline & FC. Finanse & 2 \\
\hline & FD. Public relations & 3 \\
\hline & FE. Zarządzanie zasobami ludzkimi & 8 \\
\hline & FF. Finansowanie & 3 \\
\hline & FG. Władze lokalne & 0 \\
\hline & FH. Reorganizacja & 2 \\
\hline & Fl. Samorządy & 1 \\
\hline & FZ. Inne z tej kategorii & 2 \\
\hline \multirow{10}{*}{$\begin{array}{l}\text { G. Przemysł informa- } \\
\text { cyjny, zawód } \\
\text { i szkolenia zawo- } \\
\text { dowe }\end{array}$} & GA. Przemysł informacyjny & 8 \\
\hline & GB. Przemysł oprogramowania & 0 \\
\hline & GC. Przemysł informatyczny i telekomunikacyjny & 1 \\
\hline & GD. Organizacje & 0 \\
\hline & GE. Personel & 13 \\
\hline & GF. Biografie & 2 \\
\hline & GG. Programy kształcenia & 0 \\
\hline & GH. Edukacja & 11 \\
\hline & Gl. Szkolenie & 1 \\
\hline & GZ. Inne z tej kategorii & 1 \\
\hline
\end{tabular}




\begin{tabular}{|c|c|c|}
\hline \multirow{20}{*}{$\begin{array}{l}\text { H. Źródła i kanały } \\
\text { informacji }\end{array}$} & HA. Czasopisma, gazety Periodicals, Newspapers & 11 \\
\hline & HB. Szara literatura & 0 \\
\hline & HC. Archiwalia & 2 \\
\hline & HD. Cymelia i rękopisy & 1 \\
\hline & HE. Materiały drukowane & 1 \\
\hline & HF. Mikroformy & 0 \\
\hline & HG. Źródła niedrukowane & 0 \\
\hline & $\mathrm{HH}$. Materiały audiowizualne. Multimedia & 1 \\
\hline & HI. Media elektroniczne & 2 \\
\hline & HJ. CD-ROM & 0 \\
\hline & HK. Serwery internetowe & 0 \\
\hline & HL. Bazy danych tradycyjne i sieciowe & 41 \\
\hline & HM. Komputerowe katalogi biblioteczne (OPAC) & 1 \\
\hline & HN. Czasopisma elektroniczne & 12 \\
\hline & HO. Książki elektroniczne & 1 \\
\hline & HP. Elektroniczne zasoby & 26 \\
\hline & $\mathrm{HQ}$. Strony internetowe & 16 \\
\hline & HR. Portale & 13 \\
\hline & HS. Repozytoria & 40 \\
\hline & HZ. Inne z tej kategorii & 5 \\
\hline \multirow{12}{*}{$\begin{array}{l}\text { I. Usługi informacyjne } \\
\text { i przetwarzanie } \\
\text { informacji }\end{array}$} & IA. Katalogowanie, rejestracja bibliograficzna & 6 \\
\hline & IB. Analiza zawartości & 1 \\
\hline & $\begin{array}{l}\text { IC. Języki informacyjno-wyszukiwawcze, procesy i sposoby } \\
\text { indeksowania }\end{array}$ & 3 \\
\hline & ID. Struktury danych i metadanych & 1 \\
\hline & IE. Reprezentacja wiedzy & 4 \\
\hline & IF. Wymiana informacil: protokoły, formaty danych, technologia & 2 \\
\hline & IG. Prezentacja informacji, hipertekst, hipermedia & 1 \\
\hline & IH. Systemy dokumentów graficznych & 0 \\
\hline & II. Filtrowanie & 0 \\
\hline & IJ. Wydawnictwa informacyjne & 12 \\
\hline & $\begin{array}{l}\text { IK. Projektowanie, rozbudowa, wdrażanie i konserwacja systemów } \\
\text { i usług informacyjnych }\end{array}$ & 2 \\
\hline & IZ. Inne z tej kategorii & 2 \\
\hline
\end{tabular}




\begin{tabular}{|c|c|c|}
\hline \multirow{12}{*}{$\begin{array}{l}\text { J. Obsługa techniczna } \\
\text { w bibliotekach, } \\
\text { archiwach i mu- } \\
\text { zeach }\end{array}$} & JA. Gromadzenie & 1 \\
\hline & JB. Zarządzanie wydawnictwami ciagłymi & 0 \\
\hline & JC. Selekcja zbiorów & 0 \\
\hline & JD. Skontrum & 0 \\
\hline & JE. Ewidencja zbiorów & 0 \\
\hline & JF. Ochrona papieru & 2 \\
\hline & JG. Digitalizacja & 13 \\
\hline & JH. Ochrona materiałów cyfrowych & 2 \\
\hline & Jl. Udostępnianie zbiorów & 1 \\
\hline & JJ. Dostarczanie dokumentów & 0 \\
\hline & JK. Wypożyczenia międzybiblioteczne & 1 \\
\hline & JZ. Inne z tej kategorii & 2 \\
\hline \multirow{9}{*}{$\begin{array}{l}\text { K. Technologie } \\
\text { lokalne }\end{array}$} & KA. Centra zasobów & 2 \\
\hline & KB. Budynki bibliotek, archiwów i muzeów & 0 \\
\hline & KC. Meble & 0 \\
\hline & KD. Środki transportu & 0 \\
\hline & KE. Architektura & 4 \\
\hline & KF. Planowanie, projektowanie, przeprowadzki & 0 \\
\hline & KG. Bezpieczeństwo & 0 \\
\hline & KH. Zarządzanie kryzysowe & 0 \\
\hline & KZ. Inne z tej kategorii & 0 \\
\hline \multirow{20}{*}{$\begin{array}{l}\text { L. Technologie } \\
\text { informacyjne i bi- } \\
\text { blioteczne }\end{array}$} & LA. Sieci komputerowe & 4 \\
\hline & LB. Telekomunikacja & 0 \\
\hline & LC. Internet, WWW & 16 \\
\hline & LD. Komputery & 0 \\
\hline & LE. Skanery & 0 \\
\hline & LF. Aparaty cyfrowe & 0 \\
\hline & LG. Kopiarki & 0 \\
\hline & LH. Bezpieczeństwo komputera i sieci & 0 \\
\hline & LI. Uwierzytelnianie i kontrola dostępu & 1 \\
\hline & LJ. Oprogramowanie & 8 \\
\hline & LK. Metodologia i inżynieria oprogramowania & 0 \\
\hline & LL. Zautomatyzowane przetwarzanie języka & 0 \\
\hline & LM. Zautomatyzowane wyszukiwanie tekstowe & 1 \\
\hline & LN. Systemy zarządzania bazami danych & 1 \\
\hline & LO. Obiektowe systemy zarządzania bazami danych & 0 \\
\hline & LP. Inteligentni agenci & 2 \\
\hline & LQ. Systemy automatyzacji bibliotek & 10 \\
\hline & LR. Systemy OPAC & 2 \\
\hline & LS. Wyszukiwarki & 3 \\
\hline & LZ. Inne z tej kategorii & 1 \\
\hline
\end{tabular}

Źródło: Opracowanie własne. 
Jak nietrudno zauważyć, zestawienie wszystkich dokumentów znacznie przerasta liczbę 320 pozycji wyświetlonych dla kryterium „kraj: Polska”. Mimo że zaprezentowane wyniki są obarczone dużym marginesem błędu (choćby ze względu na różny stopień szczegółowości opisu rzeczowego), w zbiorze wyraźnie dominuja publikacje tematycznie dotyczące bibliotek akademickich, zasobów elektronicznych, środków masowego przekazu i społecznych aspektów wykorzystywania informacji. Taki profil tematyczny polskich publikacji nasuwa spostrzeżenie, że ich autorzy zakresem zainteresowań wpisuja się w kierunki badań bibliologicznych prowadzone na świecie. Analiza zawartości treściowej wybranych tytułów czasopism („College and Research Libraries”, „Library Quarterly”, „Journal of Academic Librarianship”) przeprowadzona przez Ewę Głowacka ${ }^{16}$ dowiodła koncentracji uwagi badaczy właśnie na zagadnieniach dotyczących zasobów, usług i produktów elektronicznych. Ponadto - podobnie jak polski zbiór E-LIS - badania te wyraźnie uwidoczniły także obecność dużej liczby prac z zakresu wykorzystywania bibliotek, badań ich użytkowników oraz oceny jakości usług bibliotecznych, a także stosunkowo dużej i różnorodnej liczby publikacji dedykowanych pracownikom bibliotek. Najmniejszym zainteresowaniem cieszyła się teoria bibliotekoznawstwa. Niestety, choć wnioski wydaja się analogiczne, nie są one uprawnione. Wynika to przede wszystkim z niereprezentatywnej liczby publikacji polskich zamieszczonych na łamach repozytorium E-LIS. Nierównomierne tempo deponowania (por. wykres 2), nieobecność publikacji czołowych biblio- i informatologów, dublowanie tytułów (np. istnienie w zasobie tej samej treści pod postacią publikacji i prezentacji multimedialnej), różny stopień szczegółowości opisu bibliograficznego (zwłaszcza zapisu hasłowego i słów kluczowych), niedoskonałe mechanizmy wyszukiwania, a nawet błędy w ogólnym zapisie klasyfikacji (np. "Information treatement for information services” zamiast "Information treatment for information services”; „DD. Public libraries” zamiast „DC. Public libraries”) mogące dawać różny rezultat wyszukiwania nie pozwalają na podstawie zasobów E-LIS formułować ogólnych wniosków na temat kierunków rozwoju bibliotekoznawstwa i nauki o informacji. Jednak nie taki cel przyświecał powołaniu do istnienia repozytorium E-LIS.

\section{Podsumowanie}

Polskie publikacje w E-LIS istnieja. Na podstawie danych statystycznych dowieść można nawet stałego, choć nierównomiernego ich przyrostu. Cieszy fakt, że obok publikacji stricte informatologicznych do repozytorium trafiaja prace prasoznawców, historyków książki i bibliotekarzy. Udział polskich publikacji na poziomie 2,4\% w porównaniu do 24\% (3 272 publikacji) Hiszpanii czy $11 \%$ Włoch (1 486 publikacji) - krajów deponujących najwięcej, ocenić należy jako niewielki. $Z$ drugiej jednak strony, w porównaniu z innymi krajami Europy Wschodniej (Czechy - 0,5\%, Słowacja - 0.01\%, Węgry - 0,01\%, Litwa - 0,02\%, Łotwa - 0,01\%, Ukraina - 0,06\%), a nawet Stanami Zjednoczonymi (5,4\%)

${ }^{16}$ E. Głowacka: Główne współczesne kierunki badań z zakresu bibliotekoznawstwa na świecie. „Przegląd Biblioteczny” 2008, z. 1, s. 22-27. 
jest to obecność znacząca. Optymizmem napawa prawie 46\% przyrost zasobu w okresie między sierpniem 2011 r. a sierpniem 2012 r.

Bez watpienia przyrost zasobów polskiej części E-LIS to w dużej mierze zasługa polskich redaktorów, którzy niejednokrotnie samodzielnie wyszukuja publikacje i po uzyskaniu zgody autorów deponuja je w repozytorium (dotyczy to przede wszystkim materiałów konferencyjnych).

Wydaje się, że z punktu widzenia autorów największą przeszkodę w archiwizowaniu dokumentów stanowią prawa autorskie. Wielu twórców, podpisując szablonowe umowy wydawnicze, powierza wydawcy dysponowanie utworem na wszystkich polach eksploatacji. Włączenie dokumentu do repozytorium wiąże się więc z koniecznością renegocjacji umowy czy poczynienia dodatkowych ustaleń z wydawca - co niekiedy nie jest łatwe. Niestety, polscy autorzy rzadko korzystają także ze swoich praw do publikowania preprintów (26 preprintów na 320 dokumentów). Do innych czynników zniechęcających do udziału w tworzeniu repozytorium można zaliczyć jeszcze brak wiedzy na temat zasad deponowania, niedostateczną znajomość języka angielskiego i związaną z tym niechęć do posługiwania się obcojęzycznym interfejsem, brak wolnego czasu, by przeznaczyć go na autoarchiwizację, nieznajomość statusu prawnego własnych utworów, brak zrozumienia dla kwestii otwartego dostępu wśród akademickiej administracji, konserwatyzm postaw i sceptyczny stosunek do umieszczania własnych publikacji w Internecie, niedocenianie zasięgu oddziaływania repozytorium, a wreszcie niedostateczna promocja samego archiwum E-LIS ${ }^{17}$.

Ponieważ zalety zamieszczania prac w E-LIS są ewidentne ( $m$.in. zwiększenie widoczności i popularyzacja prowadzonych badań, bezpłatny dostęp do ich wyników, promocja własnego dorobku naukowego, wzrost liczby cytowań, indeksacja w wyszukiwarkach stosujących protokół OAI-PMH <<ang. Open Archives Initiative Protocol for Metadata Harvesting >>, zmniejszenie kosztów udostępniania materiałów dydaktycznych $)^{18}$, warto mieć świadomość, że obecność w jego zasobach nie zagraża ani autorytetowi naukowemu, ani tradycyjnej działalności publikacyjnej. Wręcz przeciwnie, umieszczanie prac w otwartym repozytorium stanowi antidotum na opóźnienia związane z procesem redakcji i recenzji wydawnictw drukowanych. Skoro więc nowoczesna technologia stwarza nam szansę na urzeczywistnienie idei dzielenia się wiedzą, dlaczego by z niej nie korzystać w dobrze pojętym interesie środowiska i własnym?

17 Wyniki badań na temat stosunku polskich badaczy do kwestii otwartego dostępu zob. Wdrożenie i promocja otwartego dostępu do treści naukowych i edukacyjnych: praktyki światowe a specyfika polska, przewidywane koszty, narzędzia, zalety $i$ wady. Oprac. zespół ICM pod kier. M. Niezgódki. Warszawa: Interdyscyplinarne Centrum Modelowania Matematycznego i Komputerowego Uniwersytetu Warszawskiego, Warszawa 2011, 288 s. [online]. [dostęp: 27.08.2012]. Dostępny w World Wide Web: <http://www.nauka.govpl/ fileadmin/user_upload/Nauka/Polityka_naukowa_panstwa/Analizy_raporty_statystyki/ 20120208_EKSPERTYZA_OA_ICM.pdf>.

${ }^{18}$ L. Dérfert-Wolf: Międzynarodowe archiwum..., op. cit. 


\section{Summary}

The Open Access movement has been expanding for 10 years. Electronic archives aiming primarily at provision of free, fast, and open access to knowledge for all Internet users are created according to this idea. The Eprints for Library and Information Science (E-LIS) represents one of such archives, including also Polish texts since 2005. The article presents general rules of placing publications in this repository, searching options, as well as results of statistical and thematic analysis of Polish materials. The author evaluates this set regarding frequency of publication, issue date, types of documents, and the most popular topics. 